\title{
GAMBARAN KINERJA DAN ETOS KERJA PEREMPUAN SUKU SASAK YANG BEKERJA DI DENPASAR
}

\author{
Putu Ayu Novia Viorica dan Komang Rahayu Indrawati \\ Program Studi Psikologi, Fakultas Kedokteran, Universitas Udayana \\ ayunoviaviorica@yahoo.com
}

\begin{abstract}
Abstrak
Penelitian ini fokus pada kinerja dan etos kerja perempuan suku Sasak. Perempuan suku Sasak memiliki nilai budaya dan kearifan lokal yang terkait dengan gaya bekerja mereka. Menurut Rasyidi (2008) nilai budaya yang mengikat suku Sasak antara lain adalah nilai kepemimpinan, kesetiaan, keadilan, kesejahteraan masyarakat, kepedulian terhadap lingkungan hidup, serta nilai toleransi. Salah satu kearifan lokal yang melekat pada perempuan suku Sasak adalah menenun. Menurut Rosyidi (2012), ornamen dalam kain tenun perempuan Sasak memiliki nilai budaya yakni ornamen Subahnale melambangkan kesabaran, keikhlasan dan berserah pada Tuhan Yang Maha Esa, ornamen Sabuk Peraban melambangkan gotong royong dan kekerabatan, Sri Menanti segala hal tercipta berpasangan dan saling melengkapi, Lonong Abang Ragi Genap melambangkan kesempurnaan dalam pelaksanaan upacara adat, Pucuk Rebong melambangkan kesuburan, dan Bintangan melambangkan kejayaan dan kekayaan. Nilai budaya yang mengikat perempuan Sasak dapat mempengaruhi kinerja dan etos kerja mereka dalam bekerja.

Penelitian ini menggunakan pendekatan fenomenologi dengan teknik kualitatif. Penelitian ini bertujuan untuk mengetahui gambaran kinerja dan etos kerja perempuan suku Sasak yang bekerja di Denpasar. Hasil penelitian menunjukkan bahwa gambaran kinerja perempuan suku Sasak yang bekerja di Denpasar adalah belum mampu menyesuaikan diri dengan peraturan di dunia kerja sesungguhnya, dapat bekerjasama, mengembangkan kepedulian pada atasan, hanya melakukan tugas yang diperintahkan saja, tidak memiliki inisiatif dan lebih senang bekerja sendiri. Etos kerja perempuan suku Sasak yang bekerja di Denpasar adalah cenderung tetap menampilkan perilaku yang tidak diharapkan oleh pengguna jasa perempuan suku Sasak meski mengetahui hal tersebut salah.
\end{abstract}

Kata Kunci: kinerja, etos kerja, perempuan suku Sasak

\begin{abstract}
This research focus on performance and work ethics in Sasak Women. Sasak women have culture and local wisdom that influence their performance and work ethics in workplace.

Rasyidi (2008) shows that Sasak women has six values such as leadership, faithfulness, justice, social prosperity, caring with others and tolerance each others. One of the local wisdom in Sasak Women is weave. There are six values in weave fabric ornaments such as Subahnale as patience and sincerity value, Sabuk Peraban as teamwork and kinship value, Sri Menanti as complementary value, Lonong Abang Ragi Genap as perfectness in culture ceremony, Pucuk Rebong as prosperity value, and Bintangan as glory and wealth value (Rosyidi, 2012).

This study used qualitative method with phenomenological approach. Goals of this research is to know the representation of performance and work ethics in Sasak women who works in Denpasar. This research shows that performance representation in Sasak women is willing to work in team and individual, caring to supervisor, unadaptable with supervisor regulation, and lack of initiative. Work ethics in Sasak women was perform negatively even they knows that is unhoped for work.
\end{abstract}

Keywords: performance, work ethic, Sasak women 


\section{LATAR BELAKANG}

Setiap individu menampilkan kinerja yang berbeda dalam bekerja. Perbedaan tingkat kinerja ini terjadi karena kinerja seseorang dipengaruhi oleh berbagai hal, salah satunya adalah etos kerja. Pernyataan peneliti ini didukung oleh penelitian yang dilakukan oleh Muhaimin (2013) yang mengungkapkan bahwa etos kerja secara signifikan mempengaruhi kinerja.

Etos kerja adalah sikap yang muncul atas kehendak dan kesadaran sendiri yang didasari oleh sistem orientasi nilai budaya terhadap kerja (Ismainar, 2015). Etos kerja yang dimiliki oleh individu digunakan sebagai landasan dalam bekerja sehingga kinerja yang ditampilkan memiliki ciri khas tersendiri. Ciri khas masing-masing individu dalam bekerja ini dapat berbeda satu sama lain karena etos kerja individu dipengaruhi oleh beberapa faktor salah satunya adalah faktor budaya. Pernyataan peneliti tersebut sejalan dengan Yusuf (2011), yang menyatakan bahwa etos kerja tiap individu dapat berbeda karena etos kerja dipengaruhi oleh latar belakang pribadi individu, nilai agama yang dianutnya, kondisi lingkungan, manusia dan alam disekitarnya.

Indonesia terdiri dari berbagai macam suku bangsa dengan budaya yang beragam. Keanekaragaman budaya yang dimiliki oleh Indonesia memungkinkan adanya perbedaan etos kerja pada masing-masing individu sehingga pemaknaan etos kerja pada tiap suku bangsa di Indonesia tidak dapat disamakan. Berbagai penelitian telah mengungkap gambaran etos kerja pada beberapa etnis atau suku di Indonesia.

Salah satu penelitian terkait etos kerja pada suku di Indonesia dilakukan oleh Faraby (2014) dengan memfokuskan diri pada etos kerja pedagang etnis Madura. Penelitian lain terkait etos kerja dan etnis dilakukan oleh Hasbullah (2011) yang fokus pada budaya kerja perempuan etnis Melayu. Lebih jauh lagi, penelitian yang dilakukan oleh Yvonne, Krasono, dan Suprajitno (2014) mengungkap tentang etos kerja pada etnis Tionghoa di Kota Surabaya. Ketiga penelitian terkait etos kerja pada etnis atau suku tersebut membuktikan bahwa budaya yang dibawa oleh individu dapat mempengaruhi etos dan kinerja mereka dalam bekerja. Berdasarkan temuan beberapa penelitian tersebut, peneliti tertarik untuk melakukan penelitian etos kerja terkait dengan aspek budaya khususnya pada perempuan yang berasal dari suku Sasak.

Peneliti tertarik untuk mengungkap gambaran etos kerja dan kinerja perempuan suku Sasak karena terdapat nilai budaya yang khas menyertai perempuan suku Sasak dalam bekerja. Selain itu, literatur ilmiah yang mengungkap tentang kinerja dan etos kerja perempuan suku Sasak masih tergolong minim. Sebagian besar literatur ilmiah hanyamengungkap tentang budaya suku Sasak secara umum namun belum sampai pada variabel etos kerja dan kinerja mereka.
Figur perempuan suku Sasak sangat lekat dengan figur wanita penenun. Menenun merupakan mata pencaharian tradisional yang umum dilakukan oleh perempuan suku Sasak. Perempuan suku Sasak harus mahir menenun terlebih dahulu barulah mereka boleh menikah karena kemampuan mereka dalam menenun dapat membantu suami mereka dalam mencari nafkah kelak (Sudarsana, 2015).

Rosyidi (2012) mengungkapkan bahwa proses menenun yang dilakukan oleh perempuan suku Sasak memiliki nilai-nilai terkait budaya. Nilai-nilai tersebut tercermin dalam ornamen kain tenun suku Sasak, yakni ornamen Subahnale melambangkan kesabaran, keikhlasan dan berserah pada Tuhan Yang Maha Esa, ornamen Sabuk Peraban melambangkan gotong royong dan kekerabatan, Sri Menanti segala hal tercipta berpasangan dan saling melengkapi, Lonong Abang Ragi Genap melambangkan kesempurnaan dalam pelaksanaan upacara adat, Pucuk Rebong melambangkan kesuburan, dan Bintangan melambangkan kejayaan dan kekayaan. Lebih jauh lagi Rasyidi (2008) mengungkapan bahwa perempuan suku Sasak juga memiliki keterikatan dengan nilai budaya lainnya dalam menjalani kehidupan. Nilai yang mengikat perempuan suku Sasak tersebut antara lain adalah nilai kepemimpinan, nilai kesetiaan, nilai keadilan, nilai kesejahteraan masyarakat, nilai kepedulian terhadap lingkungan hidup, serta nilai toleransi.

Seiring dengan berkembangnya zaman, perempuan suku Sasak saat ini mulai merantau dari daerah asal mereka ke daerah lain untuk mencari jenis pekerjaan yang baru. Hal ini didukung oleh data statistik yang dikeluarkan oleh BPS (2014) yang menunjukkan bahwa jumlah perempuan Nusa Tenggara Barat yang bekerja pada tahun 2014 mengalami peningkatan dari tahun sebelumnya yakni berjumlah 8.870 orang. Lebih jauh lagi, BPS (2016) jumlah angkatan kerja yang bekerja pada tahun 2015 mengalami peningkatan berjumlah $95.02 \%$ dibandingkan dengan tahun 2014 yang hanya berjumlah $94.70 \%$.

Data-data terkait perempuan suku Sasak yang mulai bekerja dipertegas oleh hasil wawancara dengan salah satu perempuan suku Sasak yang merantau. Hasil wawancara mengungkapkan bahwa narasumber pergi merantau karena di daerah asal narasumber sangat minim lapangan pekerjaan. Tidak hanya narasumber yang memutuskan untuk merantau demi mencari pekerjaan, perempuan suku Sasak lainnya banyak yang merantau untuk bekerja sebagai TKI (Tenaga Kerja Indonesia) dengan tingkat pendidikan yang tergolong rendah (Rostanti, 2015).

Bekerja sebagai pegawai di lingkungan baru bukanlah hal yang mudah bagi perempuan suku Sasak. Berbagai permasalahan timbul ketika perempuan suku Sasak memutuskan untuk bekerja di luar daerah mereka. Permasalahan ini terjadi karena adanya ketidaksiapan perempuan suku Sasak dalam memasuki dunia kerja yang 
sesungguhnya. Hal ini dapat terjadi karena sebagian besar perempuan suku Sasak belum mempersiapkan diri untuk memasuki dunia kerja yang sesungguhnya. Hasil wawancara terhadap YD selaku perempuan suku Sasak menunjukkan bahwa perempuan di daerah asal YD sebagian besar memilih untuk menikah setelah menamatkan pendidikan dibandingkan dengan bekerja.

Mengingat keterbatasan artikel maupun karya ilmiah lain yang mengungkap tentang permasalahan perempuan suku Sasak dalam bekerja, peneliti melakukan wawancara terhadap salah satu perempuan suku Sasak berinisial L. L adalah seorang perempuan suku Sasak yang saat ini bekerja di Denpasar sebagai seorang kasir. L mengaku mengalami kendala terkait proses penyesuaian diri dengan jam kerja dan konflik dengan rekan kerja.

Wawancara kedua kembali dilakukan guna memperkaya data terkait permasalahan yang dialami oleh perempuan suku Sasak dalam bekerja. Wawancara kedua dilakukan terhadap YD, salah satu perempuan suku Sasak yang bekerja di Denpasar. Berdasarkan hasil wawancara dengan YD, dapat disimpulkan bahwa perempuan suku Sasak yang diijinkan untuk bekerja oleh orang tuanya, umumnya memiliki perilaku tidak disiplin di tempat kerja. Menurut pengakuan YD, perilaku tidak disiplin ini merupakan cerminan dari perilaku perempuan suku Sasak yang tidak selalu mengikuti peraturan dan tata tertib yang diterapkan di tempat kerja. Menurut YD, hal ini terjadi karena di daerah asalnya, YD tidak terbiasa dengan peraturan yang kompleks dalam dunia kerja sehingga saat YD berada di daerah yang berbeda dengan budaya dan peraturan kerja yang lebih kompleks, YD mengalami kesulitan untuk menyesuaikan diri. YD juga mengungkapkan fakta bahwa perempuan suku Sasak sebagian besar tidak bekerja karena orang tua mereka memiliki anggapan bahwa perempuan suku Sasak akan menjadi 'nakal' jika bekerja terutama di daerah rantauan. Selain itu, perempuan suku Sasak juga sulit untuk secara aktif memunculkan inisiatif dalam bekerja karena perempuan suku Sasak terbiasa untuk hanya melakukan apa yang diperintahkan atau diucapkan oleh orang tuanya tanpa mengembangkan inisiatif pribadi.

Wawancara tidak hanya dilakukan pada perempuan suku Sasak yang bekerja di Denpasar namun wawancara juga dilakukan pada orang yang telah memiliki pengalaman dalam mempekerjakan perempuan suku Sasak. Wawancara ini dilakukan dengan tujuan untuk mengetahui bagaimana gambaran kinerja perempuan suku Sasak ditinjau dari sudut pandang pemberi kerja atau atasan. Salah satu pemilik tempat usaha dibidang perdagangan yang berhasil diwawancarai bernama ibu TR, telah mempekerjakan 10 orang perempuan suku Sasak di tempat usahanya. Hasil wawancara terhadap ibu TR menunjukkan bahwa ibu TR merasa kecewa dengan kinerja perempuan suku Sasak yang pernah bekerja untuknya.
Ibu TR merasa kecewa karena perempuan suku Sasak yang bekerja padanya tidak disiplin dalam bekerja dan tidak dapat dipercaya. Menurut pengakuan ibu TR, ia tidak ingin mempekerjakan kembali perempuan suku Sasak di tempat usahanya.

Peneliti melakukan studi lebih lanjut untuk melihat bagaimana pandangan masyarakat umum terhadap kinerja perempuan suku Sasak dengan cara menyebarkan kuesioner pada atasan atau pemilik usaha yang pernah menggunakan jasa perempuan suku Sasak. Hasil penyebaran kuesioner tersebut menunjukkan bahwa 4 dari 6 responden secara umum memiliki kesan yang positif terhadap kinerja perempuan suku Sasak namun seluruh responden mengaku masih memiliki keluhan terhadap kinerja perempuan suku Sasak.

Adanya perbedaan pandangan terhadap kinerja perempuan suku Sasak telah menarik perhatian untuk diteliti sehingga dapat diperoleh gambaran etos kerja dan kinerja perempuan suku Sasak secara lebih mendalam. Gambaran kinerja dan etos kerja perempuan suku Sasak ini dapat digunakan untuk mengetahui kinerja dan etos kerja perempuan suku Sasak yang sesungguhnya. Gambaran kinerja dan etos kerja perempuan suku Sasak ini juga dapat dijadikan pedoman dalam melakukan kegiatan pemberdayaan yang tepat bagi perempuan suku Sasak dalam bekerja sehingga perempuan suku Sasak dapat meningkatkan kualitas mereka dalam bekerja. Berdasarkan pertimbangan tersebut peneliti melakukan penelitian mengenai gambaran etos kerja dan kinerja perempuan suku Sasak yang bekerja di Denpasar untuk melihat gambaran kinerja dan etos kerja perempuan suku Sasak.

\section{Tipe Penelitian}

\section{METODE}

Metode penelitian yang digunakan pada penelitian ini adalah metode penelitian kualitatif. Peneliti menggunakan metode penelitian kualitatif karena peneliti memiliki tujuan untuk menggali lebih dalam gambaran etos kerja dan kinerja perempuan Suku Sasak yang bekerja di Denpasar dengan cara berinteraksi dengan perempuan Suku Sasak yang bekerja di Denpasar dan juga orang disekitarnya. Pertimbangan lain yang menjadi landasan peneliti dalam memilih metode penelitian kualitatif karena jumlah perempuan Suku Sasak yang merantau di Denpasar untuk bekerja masih belum terdata secara pasti oleh Dinas

Tenaga Kerja (Disnaker) Kota Denpasar sehingga peneliti mengalami kesulitan dalam menemukan responden yang sesuai dengan kriteria penelitian dalam jumlah besar. Data konkret terkait jumlah perempuan Suku Sasak yang merantau di Denpasar belum dapat terdata secara resmi karena umumnya perempuan Suku Sasak yang bekerja di Denpasar hanya bekerja pada tempat usaha perorangan dan melalui jalur individu sehingga keberadaannya tidak terdata secara resmi oleh Disnaker Kota Denpasar. 


\section{Pendekatan/Model Penelitian}

Pendekatan yang digunakan pada penelitian ini adalah pendekatan fenomenologi. Sejalan dengan pendapat yang diungkapkan oleh Yusuf (2014), peneliti menggunakan pendekatan fenomenologi dengan tujuan untuk menggali dan memahami fenomena etos kerja serta kinerja pada perempuan Suku Sasak dalam bekerja. Fenomena etos kerja dan kinerja perempuan Suku Sasak dalam bekerja diperoleh melalui proses penggalian data terhadap responden perempuan Suku Sasak yang bekerja di Denpasar dan informan responden.

\section{Unit Analisis}

Penelitian ini menggunakan unit analisis yang bersifat kelompok. Unit analisis data bersifat kelompok digunakan dengan pertimbangan bahwa peneliti ingin melihat gambaran kinerja dan etos kerja pada perempuan suku Sasak di Denpasar. Persamaan ciri kinerja dan pemaknaan etos kerja pada masing-masing responden dilihat sebagai suatu fenomena yang menggambarkan kinerja dan etos kerja perempuan Suku Sasak yang bekerja di Denpasar.

\section{Responden dan Tempat Penelitian}

\section{Responden Penelitian}

Responden penelitian dipilih berdasarkan teknik purposive sampling dengan pertimbangan bahwa peneliti ingin meneliti tentang etos kerja dan kinerja perempuan Suku Sasak, sehingga pencarian sumber data yang dibutuhkan terfokus pada kelompok perempuan Suku Sasak yang bekerja di Denpasar.

Responden penelitian yang digunakan pada penelitian ini berjumlah 3 orang. Jumlah ini digunakan dengan pertimbangan bahwa jumlah minimal responden yang direkomendasikan pada pendekatan fenomenologi adalah sebanyak tiga orang. Masing-masing responden penelitian memiliki significant others yang terlibat dalam proses penggalian data. Significant others masing-masing responden terdiri dari atasan responden dan rekan kerja responden.

Kriteria responden pada penelitian ini antara lain perempuan, suku Sasak, berusia dewasa muda (18-29 tahun). Rentang usia dewasa muda yang digunakan sesuai dengan rentang usia dewasa muda yang dikemukakan oleh Heslin (2007), lahir dan tumbuh besar di Lombok, bekerja di Denpasar, kedua orang tua berasal dari Suku Sasak, orang tua lahir dan tumbuh besar di Lombok

\section{Tempat Penelitian}

Penelitian ini dilakukan di beberapa tempat sesuai dengan lokasi pengambilan data yang sedang dilakukan. Pengambilan data dengan menggunakan teknik observasi dilakukan di tempat kerja responden dengan tujuan untuk mendapatkan data terkait kinerja responden secara lebih detail sedangkan pengambilan data dengan teknik wawancara dilakukan di tempat yang telah disepakati antara peneliti dan responden.

\section{Teknik Penggalian Data}

Penggalian data terhadap responden dilakukan dengan menggunakan metode observasi dan wawancara sedangkan penggalian data terhadap atasan dan rekan kerja responden dilakukan hanya dengan menggunakan metode wawancara. Teknik wawancara yang digunakan dalam penelitian ini adalah teknik wawancara semi terstruktur menurut Herdiansyah (2015). Teknik wawancara semi terstruktur digunakan dalam penelitian ini karena memungkinkan peneliti untuk mendapatkan gambaran kinerja dan etos kerja perempuan Suku Sasak yang bekerja di Denpasar secara umum dengan menggunakan pertanyaan terbuka namun tetap dalam konteks yang dibutuhkan dalam penelitian.

Seluruh informasi yang didapatkan melalui pertanyaan terbuka, diperdalam dengan menggunakan pertanyaan tambahan atau probing. Teknik probing yang digunakan pada penelitian ini antara lain adalah teknik informational probes, reflective probes, restatement probes, nudging probes, clearing house probes, dan mirror probes. Wawancara dilaksanakan berdasarkan panduan yang telah disusun sebelumnya. Alat bantu yang digunakan dalam proses wawancara ini adalah alat perekam suara yang berasal dari telpon seluler. Wawancara dilakukan kepada responden, atasan responden, dan rekan kerja responden.

Teknik penggalian data kedua yang digunakan pada penelitian ini adalah teknik observasi. Peneliti menggunakan observasi sebagai salah satu teknik penggalian data dengan pertimbangan bahwa peneliti ingin melihat, mengamati dan mencatat perilaku responden secara langsung sesuai dengan yang terjadi di lokasi pengamatan.

Jenis observasi yang digunakan pada penelitian ini adalah observasi tertutup dan observasi terbuka. Observasi secara tertutup dilakukan dengan menggunakan alat bantu berupa kertas, pulpen, (Closed Circuit Television) CCTV dan laptop. CCTV digunakan sebagai alat pemantau perilaku dan situasi kerja responden sedangkan kertas, pulpen dan laptop digunakan sebagai alat pencatatan perilaku dan situasi kerja responden. Penggunaan CCTV pada penelitian ini telah mendapat izin dari pemilik tempat usaha responden. Observasi secara terbuka dilaksanakan bertepatan dengan proses berlangsungnya wawancara terhadap responden dengan menggunakan alat bantu berupa kertas dan pulpen untuk mencatat perilaku dan situasi kerja responden. Fokus pengamatan pada kedua proses observasi adalah sikap dan 
situasi responden saat bekerja diantaranya lingkungan kerja responden, sikap responden dalam menyelesaikan tugas, sikap responden terhadap konsumen, sikap responden terhadap atasan dan sikap responden terhadap rekan kerja. Pengamatan ini dilakukan dengan tujuan untuk mendapatkan informasi mendalam terkait kinerja responden.

Pencatatan observasi responden dilakukan dengan tipe anecdotal records. Anecdotal records digunakan dalam penelitian ini karena anecdotal records memungkinkan pengamat untuk mencatat kejadian atau peristiwa yang penting dan menarik terkait dengan fokus penelitian.

\section{Teknik Pengorganisasian Data}

Pada penelitian ini seluruh data hasil wawancara dan observasi yang telah diperoleh, dikumpulkan ke dalam satu folder berbentuk digital. Pengumpulan data dalam bentuk digital digunakan dalam penelitian ini dengan tujuan untuk mempermudah meneliti dalam melakukan proses analisis data selanjutnya.

Seluruh data yang berupa rekaman ditransfer ke dalam bentuk tulisan dengan cara diketik dengan menggunakan aplikasi Microsoft Word 2007. Pengetikan rekaman dilakukan dengan mengetik setiap data rekaman secara mendetail.

\section{Teknik Analisis Data}

Teknik analisis data yang digunakan dalam penelitian ini adalah analisis selama di lapangan berdasarkan pada model Miles dan Huberman (dalam Yusuf, 2014) dan teknik coding dalam analisis data kualitatif menurut Strauss dan Corbin (dalam Jaccard \& Jacoby, 2010).

\section{Analisis selama di lapangan}

Teknik analisis data yang digunakan pada penelitian ini berdasarkan pada model Miles dan Huberman (dalam Yusuf, 2014) menawarkan pola umum analisis data yakni reduksi data, penyajian data (data display), serta kesimpulan/verifikasi.

Pada penelitian ini, tahap reduksi data dari hasil wawancara dan observasi menggunakan teknik coding. Mengacu pada tahapan proses coding menurut Strauss dan Corbin (2013), proses coding yang dilakukan pada penelitian ini terdiri dari tiga tahap yakni pengodean berbuka (open coding), pengodean berporos (axial coding) dan pengodean berpilih (selective coding). Pengodean berbuka (open coding) dalam penelitian ini dilakukan dengan cara membaca data yang diperoleh dengan teliti kemudian memberikan kode atau label pada setiap data. Pengodean berporos (axial coding) dalam penelitian ini dilakukan dengan cara menyusun kode-kode yang memiliki makna serupa ke dalam satu kategori. Pengodean berpilih (selective coding) dilakukan dengan cara memilih kategori inti yang berasal dari tahapan pengodean berporos (axial coding).

Pelaksanaan proses coding pada penelitian ini menggunakan bantuan Microsoft Word 2007, diberi kode menggunakan aplikasi footnote dalam Microsoft Word 2007. Penyajian data (data display) pada penelitian ini menggunakan bentuk bagan dan tabel. Pada penelitian ini, kesimpulan yang didapatkan oleh peneliti, diverifikasi oleh ahli yang berkompeten dibidang psikologi industri dan organisasi.

\section{Kreadibilitas Penelitian}

Pada penelitian ini, peneliti menggunakan teknik pemeriksaan keabsahan data penelitian dengan triangulasi. Peneliti menggunakan teknik pemeriksaan keabsahan data penelitian dengan triangulasi karena menurut Moleong (2014) triangulasi merupakan cara terbaik untuk menghilangkan perbedaan konstruksi kenyataan yang ada dalam konteks suatu studi sewaktu mengumpulkan data tentang berbagai kejadian dan hubungan dari berbagai pandangan.

Pada penelitian ini, peneliti melakukan triangulasi data dengan cara membandingkan data hasil observasi dengan data hasil wawancara, membandingkan keadaan dan perspektif responden dengan berbagai pendapat serta pandangan orang lain di sekitarnya, membandingkan hasil wawancara dan observasi satu responden dengan responden lainnya serta membandingkan hasil wawancara responden dengan teori etos kerja serta kinerja yang digunakan pada penelitian ini.

\section{Isu Etik}

Pada penelitian ini, peneliti melindungi hak-hak responden penelitian dengan Pada penelitian ini, peneliti melindungi hak-hak responden penelitian dengan memberikan informed consent atau pernyataan persetujuan kepada calon responden dan institutional approval atau persetujuan institusi terkait sebelum proses pengambilan data dilakukan. Informed consent dalam penelitian ini digunakan sebagai kontrak sosial yang disepakati oleh calon responden dan peneliti. Lembar informed consent atau lembar persetujuan yang diberikan kepada calon responden berisi nama peneliti, instansi yang menaungi peneliti, tema penelitian, tujuan penelitian, proses pengambilan data penelitian, izin penggunaan alat perekam, dan hak responden di dalam penelitian. Peneliti juga berusaha menjaga hak-hak dan privasi responden dengan cara menyamarkan identitas asli dan tempat kerja responden. Institutional approval pada penelitian ini digunakan untuk meminta persetujuan pengambilan data calon responden kepada pihak institusi terkait. 


\section{HASIL PENELITIAN}

1. Kategori 1: Karakteristik umum responden

a) Gambaran Umum

Ketiga responden dalam penelitian ini merupakan perempuan yang berasal dari suku Sasak. Ketiga responden memiliki ayah dan ibu kandung yang berasal dari Suku sasak. Masing-masing responden penelitian memiliki usia yang berbeda. Responden I saat ini berusia 21 tahun sedangkan L dan U saat ini berusia 25 tahun.

b) Proses Merantau

Terkait dengan proses dari awal merantau hingga bekerja di tempat kerja saat ini, masing-masing responden memiliki pengalaman yang berbeda. Responden $\mathrm{L}$ memutuskan untuk merantau setelah menamatkan pendidikannya di bangku SMP (VLP, L-27-28; 34). Serupa dengan responden $\mathrm{L}$, responden $\mathrm{U}$ juga memutuskan untuk merantau pertama kali setelah menamatkan pendidikannya di bangku SMP pada tahun 2008 (VEKU1, L-22; 41). Responden U merantau pertama kali untuk bekerja (VEKU1, L-45) . Pertama kali responden $U$ merantau di Bali dengan bekerja pada tetangga responden (VEKU1, L-29-30). Berbeda dengan responden $\mathrm{U}$ dan $\mathrm{L}$ yang merantau dengan tujuan untuk bekerja, responden I pada awal merantau memiliki tujuan untuk melanjutkan pendidikan di tingkat perguruan tinggi (FNOI1, L-19).

\section{c) Pengalaman kerja}

Ketiga responden penelitian ini memiliki pengalaman kerja yang berbeda selama menjalani proses merantau. Responden L telah merantau ke daerah Sumbawa dan bekerja disebuah apotek selama 5 bulan. Daerah ke dua yang menjadi tujuan merantau responden $\mathrm{L}$ adalah pulau Bali tepatnya kota Denpasar. Tempat kerja pertama responden selama merantau di Denpasar adalah tempat kerja responden saat ini. Responden L bekerja di tempat kerja saat ini dari tahun 2014 hingga sekarang. Responden L telah bekerja selama 2 tahun di tempat kerja saat ini. Responden bekerja sebagai seorang kasir di toko cabang.

Secara umum responden $U$ memiliki pengalaman merantau yang serupa dengan responden $\mathrm{L}$ yakni responden $\mathrm{U}$ pernah bekerja di daerah Sumbawa dan Bali namun responden $\mathrm{U}$ melewati proses bekerja yang berbeda dengan responden $\mathrm{L}$. Responden U bekerja pertama kali merantau ke Bali pada tahun 2008 untuk ikut dengan kakak responden yang telah lebih dahulu bekerja di Bali (VEKU1, L-22; 41). Selama 4 bulan responden $\mathrm{U}$ bekerja di tempat kerja pertama, responden tidak mendapatkan gaji (VEKU1, L-88). Responden U bekerja selama satu bulan dua minggu sebagai pengasuh anak di daerah Gianyar tersebut (VEKU1, L-73-74). Setelah responden $U$ bekerja sebagai pengasuh anak di Gianyar, responden $U$ memutuskan untuk pergi ke daerah Sumbawa untuk bekerja (VEKU1, L-106-107). Responden bekerja di daerah Sumbawa sebagai penjaga warung di pasar selama kurang lebih satu bulan (VEKU1, L-109; 125). Setelah responden $U$ bekerja sebagai penjaga warung di Sumbawa, responden kembali ke kampung halaman di daerah Lombok Timur untuk menjadi buruh tembakau selama tiga bulan (VEKU1, L-173; 175). Setelah menjadi buruh tembakau responden $\mathrm{U}$ merantau kembali ke Bali dan bekerja di tempat kerja saat ini selama 5 tahun 4 bulan (VEKU1, L-189).

Responden I hanya memiliki pengalaman bekerja di Bali. Responden I memiliki pengalaman bekerja di dua tempat sebelum bekerja di tempat kerja saat ini. Sebelum responden I bekerja untuk pertama kali, responden I melamar di tiga tempat. Tempat pertama responden I melamar kerja adalah salah satu Perseroan Terbatas (PT) di daerah Renon. Responden I mendapat panggilan kerja pertama kali di Best English dan responden I langsung bekerja di hari yang sama dengan hari responden mendapat panggilan kerja. Setelah seminggu bekerja di Best English responden I mendapat panggilan kerja ke dua di tempat kerja saat ini (VEKI 01, L29-30). Responden I memutuskan untuk resign dari Best English dan bekerja di tempat kerja saat ini sebagai staf administrasi (VEKI 01, L-34). Responden telah bekerja di tempat kerja saat ini selama 2 tahun (VAIK 01, L-56).

\section{Kategori 2: Kinerja}

Berdasarkan hasil wawancara terhadap ketiga responden penelitian, ditemukan fakta bahwa terdapat dua persamaan sifat atau karakter yang terdapat pada ketiga responden penelitian. Salah satu sifat atau karakter yang ditemukan pada ketiga responden penelitian adalah lebih senang bekerja sendiri (VEKL 01, L-618-619; VKL 01, L-35-36; VEKI 01,L903). Selain lebih senang bekerja seorang diri, ketiga responden juga memiliki karakter kurang inisiatif dalam bekerja. Karakter kurang memiliki inisiatif dalam bekerja pada ketiga responden diungkapkan oleh atasan ketiga responden penelitian (VAL1K, L-125; VAUK 01, L-645-647; VAIL, L530). Ketiga responden penelitian juga diketahui hanya mengerjakan tugas yang diperintahkan saja (VAL1K, L-260261; VEKI 01,L-948-949) dan masih sering melakukan pelanggaran dalam melakukan tugas. Pelanggaran yang dilakukan oleh ketiga responden penelitian diantaranya adalah datang terlambat ke tempat kerja dan tidak mentaati peraturan. Hal ini diungkapkan oleh atasan ketiga responden penelitian dan dibenarkan pula oleh responden penelitian (VEKL 01, L563-565; VEKU1, L-458; VKIH, L-399). Responden penelitian belum mengembangkan kompetensi yang dibutuhkan pada pekerjaan ketiga responden secara utuh (VAL1K, L-257-258; VAUK 02, L-464-466; VRKI-01 , L170) sehingga pencapaian kerja dan target yang mampu diraih oleh ketiga responden masih tergolong minim. Rendahnya pencapaian target pada ketiga responden juga disebabkan oleh perilaku melanggar peraturan dan kesalahan dalam bekerja (FNLH1, L-57-63; VUK1, L-81; VAIL, L-407). Terkait 
dengan hubungan yang terjalin antara responden penelitian dengan orang-orang di lingkugan kerja diketahui bahwa ketiga responden mampu bekerja sama dengan rekan kerja lainnya (VRKL, L-174-175; VUK1, L-106; VAIL, L-521) meskipun ketiga responden pernah terlibat konflik dengan rekan kerja (VEKL 01, L-835-836; VRKU 01, L-200; VEKI 01,L-56).

\section{Kategori 3: Etos kerja}

Hasil penelitian menunjukkan bahwa beberapa hasil penelitian pada aspek kinerja memiliki keterkaitan dengan aspek etos kerja. Aspek kinerja yang memiliki keterkaitan dengan aspek etos kerja tercermin dalam perilaku pelanggaran yang dilakukan ketiga responden dalam bekerja dan pola hubungan yang terbangun antara responden dengan rekan kerja. Terkait dengan etos kerja, ketiga responden diketahui merasa bersyukur atas pekerjaan yang dimiliki saat ini (VEKL 01, L-30-31; VEKU1, L-282). Salah satu alasan yang menyebabkan ketiga responden merasa bersyukur atas pekerjaan yang dimiliki saat ini adalah kemandirian ketiga responden dalam memenuhi kebutuhan pribadi (VEKL 01, L26-30; VUK1, L-365-366; VEKI 01,L-522). Selain merasa bersyukur, ketiga responden penelitian juga diketahui tetap melakukan prilaku yang tidak diharapkan dalam bekerja meskipun telah mengetahui bahwa perilaku tersebut salah.

\section{PEMBAHASAN DAN KESIMPULAN}

1. Kategori 1: Karakteristik umum responden

a. Gambaran umum

Ketiga responden penelitian saat ini berada pada rentang usia 18-29 tahun yakni responden I berusia 21 tahun, responden $\mathrm{L}$ dan $\mathrm{U}$ berusia 25 tahun. Usia 18-29 tahun merupakan rentang usia fase dewasa muda. Menurut Heslin (2007), usia dewasa muda yakni 18-29 tahun merupakan usia umum bagi individu untuk bekerja. Meskipun berada pada rentang usia dewasa muda, namun secara spesifik ketiga responden berada pada fase dewasa muda yang berbeda. Responden I yang berusia 21 tahun saat ini sedang berada pada fase transisi awal dewasa muda sedangkan responden $U$ dan L yang berusia 25 tahun saat ini sedang berada pada fase kehidupan dewasa awal. Pengkategorian fase dewasa muda ini sesuai dengan pernyataan Dariyo (2003) yang mengemukakan bahwa fase transisi dewasa awal berada pada rentang usia 1722 tahun sedangkan fase kehidupan dewasa awal berada pada rentang usia 22-28 tahun.

Responden I pada usia 21 tahun saat ini masih menempuh pendidikan pada tingkat perguruan tinggi di salah satu perguruan tinggi swasta di Denpasar, namun responden I juga telah bekerja pada suatu tempat usaha sebagai admin. Sebelum bekerja di tempat kerja saat ini, responden I pernah bekerja di dua tempat berbeda di Kota Denpasar. Mengacu pada Dariyo (2003), saat ini responden I telah melakukan tugas perkembangan yang sesuai dengan fase transisi dewasa awal. Dariyo (2003) mengungkapkan bahwa fase transisi awal dewasa muda memiliki tugas mempersiapkan diri untuk hidup secara mandiri dan terlepas dari orang tua dengan cara menimba ilmu dan keahlian melalui pendidikan formal maupun pendidikan non formal. Responden I yang saat ini sedang menempuh pendidikan telah mencerminkan teori fase transisi dewasa awal yang dikemukakan oleh Dariyo (2003) namun responden I telah selangkah lebih maju dalam hal bekerja.

Proses yang dilalui oleh responden I dalam menempuh pendidikan dan bekerja tidak mendapat dukungan dari ibu responden I. Ketiadaan dukungan dari ibu responden I terhadap keinginan responden untuk melanjutkan pendidikan dan bekerja tercermin dalam perilaku meminta responden I untuk berhenti bekerja dan berhenti kuliah. Berbeda dengan responden I, responden $\mathrm{U}$ dan $\mathrm{L}$ pernah merantau ke daerah Sumbawa sebelum akhirnya bekerja di tempat kerja saat ini. Responden L dan U mulai bekerja setelah menamatkan pendidikannya di tingkat SMP. Situasi Situasi responden L dan U sesuai dengan tugas perkembangan pada fase kehidupan dewasa awal yang dinyatakan oleh Dariyo (2003). Menurut Dariyo (2003) pada fase kehidupan awal dewasa, individu dari masyarakat maju akan menempuh pendidikan menengah (SMU), akademi atau universitas namun individu dari masyarakat yang belum maju secara intelektual umumnya hanya menamatkan pendidikan di bangku SMA bahkan SD/SMP, kemudian individu akan memilih dan menekuni karir sesuai dengan minat dan bakat.

\section{b. Proses merantau}

Ketiga responden penelitian saat ini sedang bekerja di Denpasar, namun proses yang dilalui oleh ketiga responden penelitian agar mampu merantau saat ini berbeda-beda. Responden L dan U merantau setelah tamat SMP dengan tujuan untuk mencari pekerjaan sedangkan responden I merantau setelah menamatkan pendidikannya di bangku SMA dengan tujuan untuk melanjutkan pendidikan ke jenjang perguruan tinggi. Masing-masing faktor pendorong awal ketiga responden untuk bekerja sesuai dengan faktor pendorong perpindahan penduduk menurut Suryaningsih (2013). Suryaningsih (2013) mengungkapkan bahwa faktor pendorong perpindahan penduduk terdiri dari proses kemiskinan di daerah, lapangan kerja yang hampir tidak ada, pendapatan yang rendah, adat istiadat yang kuat, faktor keamanan, serta melanjutkan pendidikan.

\section{c. Pengalaman Kerja}

Gambaran yang serupa dari pengalaman kerja ketiga responden adalah adanya turnover yang cepat pada ketiga responden. Turnover adalah pengunduran diri permanen secara sukarela maupun tidak sukarela dari suatu organisasi. Ketiga responden penelitian memiliki faktor penyebab turnover yang hampir serupa yakni terkait dengan ketidakpuasan terhadap gaji, ketiadaan kesempatan dalam 
menjalankan ibadah, dan adanya perlakuan tidak menyenangkan dari atasan. Gambaran terkait alasan turnover pada ketiga responden penelitian sejalan dengan faktor penyebab turnover yang diungkapkan oleh Smith (2009). Smith (2009) mengungkapkan bahwa faktor turnover karyawan terdiri dari perilaku tidak sopan atau tidak menyenangkan, ketidakseimbangan antara kehidupan dan pekerjaan, ketidaksesuaian antara pekerjaan dengan harapan, missalignment pada karyawan, merasa tidak dihargai dengan baik, rendahnya pemberian pelatihan dan umpan balik, kemampuan pengambilan keputusan yang rendah, keahlian yang tidak adekuat, ketidakstabilan organisasi, keyakinan dan kenyamanan yang terganggu, dan ketiadaan peluang.

2. Kategori 2: Kinerja

Berdasarkan hasil penggalian data terhadap ketiga responden dan informan penelitian, ditemukan fakta bahwa ketiga responden memiliki suatu ciri trait yang serupa satu dengan lainnya. Persamaan ciri trait yang ditemukan pada ketiga responden antara lain adalah ketiga responden penelitian tidak memiliki inisiatif dalam bekerja dan lebih senang bekerja seorang diri dibandingkan dengan bekerja bersama orang lain. Persamaan ketiga trait responden penelitian ini terjadi karena adanya pengaruh budaya asal ketiga responden yakni budaya suku Sasak. Pengaruh budaya terhadap persamaan trait dari ketiga responden penelitian dapat dijelaskan oleh teori yang dikemukakan oleh Ivancevich, Konopaske, dan Matteson, (2007), yang menyatakan bahwa faktor yang mempengaruhi sifat dari kepribadian seseorang diantaranya adalah faktor keturunan, budaya, hubungan orang tua-anak dan keluarga, serta kelas sosial dan kekuatan kelompok lain.

Ciri trait tidak memiliki inisiatif pada ketiga responden tercermin dalam perilaku hanya melakukan tugas yang diperintahkan saja tanpa mengembangkan inisiatif pribadi dalam melakukan tugas lain. Secara budaya, perilaku tidak memiliki inisiatif pada perempuan suku Sasak terkait dengan budaya patriarki yang dianut oleh suku Sasak. Budaya patriarki merupakan suatu budaya yang menempatkan posisi laki-laki lebih tinggi dibandingkan posisi perempuan. Menurut Kurniawan dan Mariana (2012) suku Sasak lekat dengan budaya partiarki yang menempatkan laki-laki pada struktur yang lebih tinggi dibandingkan dengan perempuan. Lebih jauh lagi, hasil penelitian yang dilakukan oleh Rosilawati (2014) menunjukkan bahwa sistem patriarki yang mengikat perempuan suku Sasak memposisikan laki-laki sebagai penguasa dan pengambil kebijakan sedangkan perempuan tidak memiliki akses yang signifikan dalam semua lini kehidupan. Posisi laki-laki yang berkedudukan sebagai penguasa dan pengambil kebijakan menjadi salah satu faktor yang mempengaruhi kemampuan perempuan suku Sasak dalam memunculkan inisiatif. Inisiatif berarti mengambil langkah proaktif untuk menuju kedepan, tidak menunggu, tidak menjadikan masalah, tantangan, hambatan atau kekurangan sebagai alasan untuk memulai sesuatu (Pella \& Inayati, 2011). Posisi laki-laki sebagai pengambil kebiijakan dan minimnya akses perempuan dalam semua lini kehidupan menghambat peluang perempuan suku Sasak dalam mengambil langkah proaktif untuk menuju kedepan sehingga perempuan suku Sasak cenderung menunggu kebijakan atau keputusan dari pihak lain dibandingkan dengan mengambil keputusan secara pribadi. Pernyataan peneliti ini diperkuat oleh hasil pre-eliminary study terhadap informan yang merupakan perempuan suku Sasak. Informan pre-eliminary study tersebut mengungkapkan bahwa di daerah responden, perempuan tidak berpikir tentang masa depan (VYP, L-50-52). Informan pre-eliminary study mengaku bahwa dirinya terbiasa untuk melakukan sesuatu semampu dirinya tanpa memunculkan inisiatif untuk lebih maju (VYP, L-220-222).

Gambaran yang muncul pada ketiga responden terkait lebih senang bekerja seorang diri, didasari oleh hal yang serupa yakni ketiga responden merasa lebih mudah menyesuaikan proses penyelesaian pekerjaan. Gambaran lebih senang bekerja seorang diri karena merasa lebih mudah menyesuaikan proses penyelesaian pekerjaan dapat dijelaskan melalui gaya kerja menenun sebagai bagian dari kearifan lokal perempuan suku Sasak. Berdasarkan berita yang dikutip dari JPNN (2016) diketahui bahwa budaya menenun melekat erat pada perempuan suku Sasak. Budaya menenun yang diwariskan secara turun temurun memiliki keunikan pada aspek gaya kerja. Seorang penenun bekerja seorang diri untuk menyelesaikan satu kain tenun dan tidak ada batasan waktu khusus terkait target penyelesaian pembuatan kain tenun. Hal ini ditegaskan oleh Ditindb (2015) yang mengungkapkan bahwa proses menenun kain dilakukan tanpa adanya batasan waktu khusus. Gaya kerja dalam menenun yang dilakukan seorang diri dan ketiadaan batasan waktu dalam proses penyelesaian kain tenun menjadikan ketiga respoden terbiasa untuk bekerja seorang diri dan mengontrol proses penyelesaian tugas secara mandiri sehingga ketiga responden penelitian merasa lebih senang bekerja seorang diri dibandingkan dengan bekerja bersama orang lain.

Terkait dengan proses pelaksanaan tugas, ketiga responden diketahui memiliki ciri yang sama dalam proses pelaksanaan tugas yakni ketiga responden hanya mengerjakan tugas yang diperintahkan saja. Ciri hanya mengerjakan tugas yang diperintahkan memiliki keterkaitan dengan ciri tidak memiliki inisiatif yang ditemukan pada ketiga responden. Menurut Pella dan Inayati, (2011) inisiatif berarti mengambil langkah proaktif untuk menuju ke depan, tidak menunggu dan bersedia untuk tidak menjadikan masalah, tantangan, hambatan, atau kekurangan sebagai alasan untuk memulai sesuatu. Sikap ketiga responden penelitian yang hanya mengerjakan tugas yang diperintahkan secara tidak langsung memiliki arti bahwa ketiga responden penelitian menunggu 
hingga mendapatkan perintah untuk menjalankan tugas. Hasil wawancara dan observasi juga menunjukkan bahwa ketiga responden penelitian belum mampu menyesuaikan diri dengan peraturan yang diberikan oleh atasan. Hal ini terlihat dari sikap tidak mentaati peraturan dengan baik dan masih melakukan kesalahan dalam pelaksanaan tugas. Perilaku tidak mentaati peraturan berulang kali di lingkungan kerja dan melakukan kesalahan dalam pelaksanaan tugas dapat terjadi karena adanya ketidaksiapan dalam menghadapi dunia kerja yang sesungguhnya. Ketidaksiapan ini muncul karena sebagian besar perempuan suku Sasak masih memilih untuk menikah setelah menamatkan pendidikan dibandingkan dengan bekerja. Selain itu, lingkungan sekitar seperti orang tua juga belum mendukung sepenuhnya anak perempuan mereka untuk bekerja. Persiapan individu terkait dengan pengetahuan kerja, keterampilan kerja, etika dalam bekerja dan hal lainnya menjadi penting karena persiapan tersebut dapat menentukan keberhasilan individu dalam menyesuaikan diri dengan lingkungan kerja dan menampilkan kinerja yang diharapkan. Schaie (dalam Papalia, Olds, \& Feldman, 2009) mengungkapkan bahwa individu mendapatkan segala informasi dan keterampilan sebagai persiapan untuk turut serta di masyarakat pada fase remaja dan masa anak-anak kemudian menggunakan pengetahuan yang dimiliki untuk mengejar tujuan seperti karir dan keluarga pada masa dewasa awal.

Persiapan dalam memasuki dunia kerja juga mempengaruhi pemenuhan kompetensi yang dibutuhkan dalam bekerja pada perempuan suku Sasak. Minimnya kesiapan ketiga repsonden dalam memasuki dunia kerja dapat terjadi karena kurangnya informasi dan keterampilan yang diberikan pada ketiga responden sebelum memasuki dunia kerja sehingga saat ketiga responden penelitian harus mengadapi dunia kerja yang sesungguhnya, ketiga responden penelitian belum mampu memenuhi keterampilan yang dibutuhkan secara maksimal. Salah satu teori yang mendukung pernyataan ini adalah teori perkembangan kognitif Schaie (dalam Papalia, Olds, \& Feldman, 2009) yang mengungkapkan bahwa pada masa dewasa awal, individu tidak lagi memperoleh pengetahuan dan keterampilan karena individu hanya menggunakan pengetahuan yang dimiliki untuk mengejar tujuan seperti karir dan keluarga. Menurut Schaie (dalam Papalia, Olds, \& Feldman, 2009) individu mendapatkan segala informasi dan keterampilan sebagai persiapan untuk turut serta di masyarakat pada fase remaja dan masa anak-anak.

Persiapan yang belum matang dalam menghadapi dunia kerja juga terkait dengan pencapaian yang dilakukan dalam bekerja. Ketidakberhasilan ketiga responden dalam mencapai goal yang ditetapkan oleh atasan memiliki keterkaitan dengan kemampuan ketiga responden dalam memenuhi tugas perkembangan pada fase dewasa awal. Menurut Papalia, Olds, dan Feldman (2009), pada fase dewasa awal, individu berada pada tahap pencapaian atau achieving stage. Tahap pencapaian ini dicirikan dengan menggunakan pengetahuan yang dimiliki untuk mencapai tujuan seperti karir dan keluarga. Ketiga responden penelitian sampai saat ini masih belum mampu memenuhi kompetensi yang dibutuhkan pada posisi saat ini karena ketiga responden masih belum memiliki pemahaman utuh terhadap tugas yang harus dikerjakan. Hal ini menjadi salah satu faktor yang menyebabkan ketidakmaksimalan kinerja pada ketiga responden.

Berdasarkan hasil penggalian data terhadap responden dan informan penelitian diketahui bahwa ketiga responden penelitian pernah terlibat konflik dengan masingmasing rekan kerja responden. Konflik yang terjadi antara ketiga responden penelitian dengan masing-masing rekan kerja tergolong kedalam tipe interpersonal conflict. Menurut Aamodt (2010) merupakan konflik yang terjadi antar individu. Aamodt (2010) menegaskan bahwa dalam dunia kerja, interpersonal conflict dapat terjadi antara dua karyawan, atasan dengan bawahan, karyawan dengan pelanggan atau karyawan dengan vendor. Konflik interpersonal yang muncul pada ketiga responden disebabkan oleh faktor ketidakpercayaan pada rekan kerja dan ketidakcocokan antar pribadi. Faktor ketidakcocokan antar pribadi sebagai pemicu konflik termasuk kedalam kategori personality menurut Aamodt (2010). Aamodt (2010) mengungkapkan bahwa faktor personality dapat menjadi salah satu pemicu terjadinya konflik karena adanya ketidaksesuaian kepribadian antar individu. Faktor ketidakpercayaan sebagai hal yang mendasari konflik responden dengan rekan kerja termasuk kedalam kategori beliefs menurut Aamodt (2010). Aamodt (2010) mengungkapkan bahwa beliefs merupakan salah satu penyebab konflik yang didasari oleh adanya ketidakpercayaan antar individu yang mengalami konflik.

Konflik yang terjadi antara ketiga responden penelitian dengan rekan kerja tidak menutup hubungan positif yang terbangun antara responden penelitian dengan atasan. Ketiga responden penelitian menunjukkan rasa peduli terhadap atasan mereka. Rasa peduli ini tercermin dalam perilaku menyayangi atasan, berusaha menyenangkan hati atasan, dan menambah jam kerja dengan keinginan sendiri. Kepedulian ketiga responden penelitian terhadap atasan merupakan cerminan dari salah satu nilai budaya yang tertanam pada suku Sasak menurut Rasyidi (2008) yakni nilai kepedulian terhadap lingkungan hidup khususnya lingkungan sosial.

Selain memiliki rasa peduli pada atasan, hasil penelitian juga menunjukkan bahwa ketiga responden penelitian mampu bekerjasama dengan rekan kerja saat bekerja. Perilaku mampu bekerjasama pada ketiga responden tercermin dalam kekompakan responden L dan rekan kerja dalam bekerja, kemampuan responden $U$ untuk bekerjasama 
pada waktu tertentu dengan rekan kerja, serta responden I yang memiliki kemampuan teamwork yang baik menurut atasan responden I. Kemampuan menjalin kerjasama pada ketiga responden penelitian memiliki keterkaitan dengan nilai budaya suku Sasak khususnya pada seni menenun. Ornamen kain tenun suku Sasak yang dikenal dengan ornamen sabuk peraban melambangkan nilai kerjasama dan gotong royong. Nilai budaya yang tertuang dalam ornamen Sabuk Peraban perempuan suku Sasak dapat mempengaruhi karakter perempuan suku Sasak dalam menjalin kerja sama dalam bekerja.

\section{Etos kerja}

Berdasarkan hasil penelitian diketahui bahwa kinerja yang ditampilkan oleh ketiga responden juga merefleksikan gambaran etos kerja yang dimiliki oleh repsonden penelitian. Hal ini dapat terjadi karena secara teoritis, etos kerja dan kinerja saling mempengaruhi secara positif satu dengan yang lainnya. Hal ini memiliki makna bahwa gambaran kinerja yang dimiliki oleh individu dapat mencerminkan pola etos kerja yang dimiliki individu. Kinerja yang tinggi pada individu dapat merefleksikan tingginya etos kerja yang dimiliki oleh individu dan sebaliknya jika kinerja yang ditampilkan oleh individu tergolong rendah maka dapat dikatakan pula bahwa etos kerja yang dimiliki oleh individu tersebut tergolong rendah. Pernyataan peneliti ini mengacu pada hasil penelitian Husni (2014) yang mengungkapkan bahwa terdapat hubungan yang signifikan antara etos kerja dengan kinerja. Lebih jauh lagi Husni (2014) mengungkapkan bahwa etos kerja merupakan salah satu faktor yang mempengaruhi kinerja. Penelitian lainnya yang mengungkap tentang hubungan kinerja dan etos kerja dilakukan oleh Muhaimin (2013). Penelitian Muhaimin (2013) mengungkapkan bahwa etos kerja guru berpengatuh secara positif dan signifikan terhadap kinerja guru.

Berdasarkan hasil penelitian, diketahui bahwa ketiga responden penelitian merasa bersyukur atas pekerjaan yang dimiliki saat ini. Ketiga responden penelitian merasa bersyukur atas pekerjaan yang dimiliki saat ini karena pekerjaan ketiga responden telah memampukan ketiga responden untuk memenuhi kebutuhan secara mandiri. Rasa syukur yang dimiliki oleh ketiga responden terhadap pekerjaan mereka saat ini mencerminkan salah satu formulasi etos kerja menurut Sinamo (2011) yakni kerja adalah rahmat. Menurut Sinamo (2011) kerja adalah rahmat merupakan kesadaran dan pengakuan bahwa kerja adalah anugerah Tuhan. Sejalan dengan rasa syukur ketiga responden terhadap pekerjaan saat ini, kemampuan ketiga responden penelitian dalam memenuhi kebutuhan secara mandiri mencerminkan formulasi etos kerja Sinamo (2011) khususnya kerja adalah kehormatan. Sinamo (2011) mengungkapkan bahwa secara finansial kerja adalah kehormatan ditandai dengan adanya pekerjaan yang memampukan individu untuk mandiri.
Hasil penelitian juga mengungkapkan bahwa ketiga responden secara umum memahami hal yang diharapkan dan tidak diharapkan dari diri mereka oleh pengguna tenaga kerja. Pemahaman responden penelitian terhadap hal yang diharapkan dan tidak diharapkan dalam bekerja tercermin pada pemahaman ketiga responden terhadap pelanggaran yang dilakukan dalam bekerja. Meskipun telah memahami hal yang diharapkan dan tidak diharapkan dari mereka namun ketiga responden penelitian masih cenderung menampilkan perilaku yang tidak diharapkan dalam bekerja. Hal ini dapat terjadi karena meskipun pekerjaan ketiga responden penelitian tergolong dalam sektor formal namun peraturan, deskripsi jabatan, kriteria penghargaan dan sanksi di tempat kerja belum dijabarkan secara rinci dan tertulis sehingga ketiga responden penelitian belum memiliki pemahaman yang utuh dan pasti terkait dengan rincian tugas yang dibebankan pada mereka.

Faktor lain yang menyebabkan ketiga responden penelitian tetap menampilkan perilaku yang tidak diharapkan dalam bekerja karena adanya ketidaksesuaian antara nilai-nilai dan keinginan dalam bekerja pada ketiga responden dengan nilainilai dan keinginan yang ditetapkan oleh atasan atau pengguna tenaga kerja. Menurut Morris dan Campion (dalam Aamodt, 2010) adanya ketidaksesuaian antara nilai, kebutuhan dan keinginan karyawan dengan apa yang harapkan oleh pengguna tenaga kerja dapat menyebabkan rendahnya motivasi dan kepuasan karyawan.

Berdasarkan hasil penelitian ditemukan bahwa ketiga responden penelitian terbiasa untuk bekerja seorang diri dan mengontrol proses penyelesaian tugas secara mandiri. Ketiga responden penelitian yang terbiasa untuk mengontrol proses penyelesaian tugas secara mandiri akan menyelesaian tugas berdasarkan norma dan ketentuan pribadi. Hal ini secara tidak langsung berdampak pada kesulitan responden penelitian dalam mengikuti peraturan yang ditetapkan oleh orang lain. Kesulitan yang dialami oleh ketiga responden penelitian dalam mengikuti peraturan yang ditetapkan oleh pengguna tenaga kerja atau atasan dapat memicu munculnya permasalahan dalam bekerja dan rendahnya kinerja ketiga responden.

Adanya ketidaksesuaian antara nilai kebutuhan dan keinginan ketiga responden penelitian dengan harapan pengguna tenaga kerja, bukan satu-satunya faktor yang dapat mempengaruhi rendahnya kinerja ketiga responden. Rendahnya kemampuan ketiga responden penelitian dalam menampilkan kinerja yang diharapkan oleh pengguna tenaga kerja juga dapat disebabkan oleh rendahnya regulasi diri yang dimiliki oleh ketiga responden penelitian. Regulasi diri adalah cara individu untuk mengontrol dan mengarahkan tindakannya sendiri (Taylor, Peplau, \& Sears, 2009). Ketidakmampuan ketiga responden dalam menaati peraturan dan menampilkan kinerja yang diharapkan oleh pengguna tenaga kerja merupakan cerminan dari ketidakmampuan rendahnya regulasi diri ketiga responden penelitian. 


\section{GAMBARAN KINERJA DAN ETOS KERJA PEREMPUAN SUKU SASAK}

Secara budaya, perilaku negatif yang tetap ditampilkan oleh ketiga responden penelitian meskipun telah memahami bahwa perilaku tersebut tidak diharapkan, memiliki keterkaitan dengan fenomena yang terjadi di kalangan perempuan suku Sasak yakni memilih untuk berumah tangga setelah menamatkan pendidikan dibandingkan dengan bekerja. Hal ini memiliki keterkaitan karena fenomena menikah setelah menamatkan pendidikan yang masih umum terjadi pada perempuan suku Sasak menjadikan perempuan suku Sasak belum siap untuk memasuki dunia kerja yang sesungguhnya. Ketidaksiapan ini terjadi karena perempuan suku Sasak belum mempersiapkan diri mereka secara matang untuk memasuki dunia kerja yang sesungguhnya. Ketidaksiapan ini juga dipicu oleh rendahnya dukungan lingkungan sekitar perempuan suku Sasak untuk bekerja. Fakta ini peneliti temukan dari hasil pre-eliminary study terhadap perempuan suku Sasak. Salah satu informan preeliminary study penelitian berinisial $\mathrm{Y}$ menyatakan bahwa di daerah informan Y sebagian besar perempuan memilih untuk menikah setelah menamatkan pendidikannya dan tidak dipersiapkan untuk bekerja pasca menamatkan pendikan formal. Fenomena menikah setelah menamatkan pendidikan juga diperkuat oleh pandangan orang tua di daerah responden yang lebih memilih untuk menikahkan anak perempuan mereka dibandingkan dengan mengizinkan anak perempuan untuk bekerja. Pandangan orang tua yang memilih untuk menikahkan anak perempuan mereka dibandingkan dengan mengizinkan bekerja didasari oleh pandangan bahwa anak perempuan jika bekerja apalagi hingga merantau dapat berubah menjadi anak yang nakal. Pernyataan informan $\mathrm{Y}$ diperkuat oleh pernyataan responden penelitian berinisial I yang mengungkapkan bahwa di daerah responden I masih sangat kental pandangan yang menilai bahwa kedudukan lakilaki jauh lebih tinggi dibandingkan dengan perempuan. Lebih jauh lagi, orang tua responden I menilai pendidikan tinggi tidak penting bagi anak perempuan dari suku mereka karena pada akhirnya anak perempuan hanya akan menjadi ibu rumah tangga.

Pandangan terhadap posisi perempuan pada budaya informan $\mathrm{Y}$ dan responden $\mathrm{I}$ mencerminkan rendahnya dukungan pada perempuan untuk mengejar pendidikan dan bekerja. Rendahnya dukungan yang diberikan pada perempuan di daerah responden I dan informan $\mathrm{Y}$ untuk bekerja, mempengaruhi rendahnya peluang yang dimiliki perempuan untuk mendapatkan pelatihan pra bekerja yang sangat bermanfaat dalam memperkenalkan dunia kerja. Hal ini berdampak lebih lanjut pada kemampuan perempuan dari daerah responden I dan informan Y dalam memenuhi tuntutan yang diharapkan pengguna tenaga kerja terhadap mereka. Lingkungan daerah responden I dan informan $\mathrm{Y}$ yang tidak mempersiapkan perempuan untuk bekerja menyebabkan perempuan dari daerah mereka cenderung tidak siap dalam menghadapi dunia kerja sehingga sikap dan perilaku kerja yang ditampilkan tergolong rendah.

Hasil pre-eliminary study terhadap responden $\mathrm{Y}$ didukung pula oleh teori yang dijabarkan Anoraga (dalam Probowati, 2012) terkait faktor-faktor yang mempengaruhi etos kerja. Menurut Anoraga (dalam Probowati, 2012) kualitas etos kerja ditentukan oleh sistem orientasi budaya masyarakat yang bersangkutan. Lebih lanjutkan lagi, Anoraga (dalam Probowati, 2012) mengungkapkan bahwa masyarakat yang memiliki nilai budaya maju akan memiliki etos kerja yang tinggi, sebaliknya masyarakat yang memiliki sistem nilai budaya yang konservatif akan memiliki etos kerja yang rendah, bahkan tidak memiliki etos kerja.

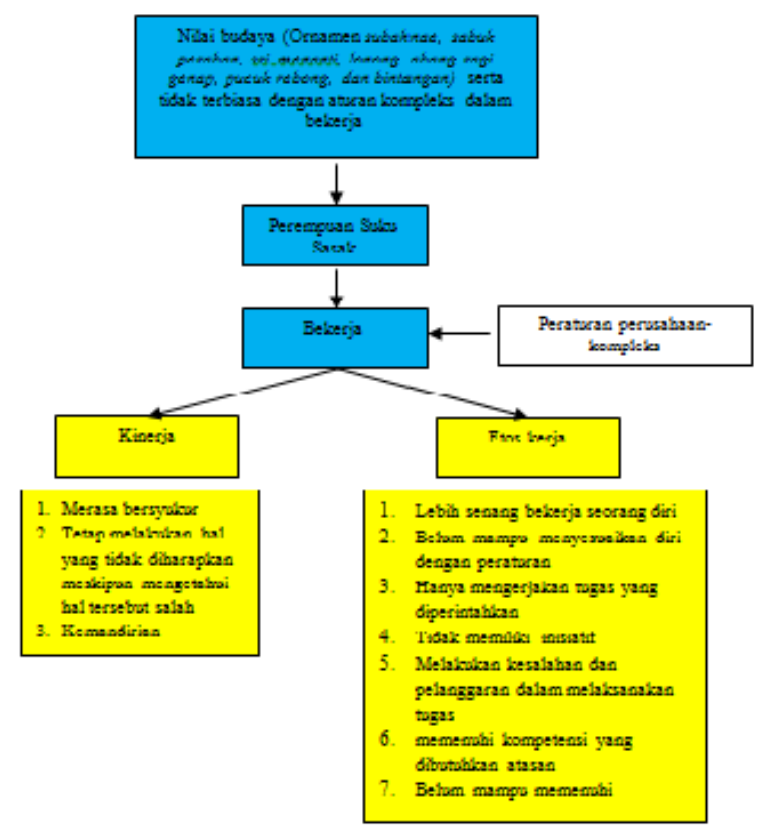

Dagan 1.

Bagan Kinerja dan Etos Kerja Perempuan Suku Sasak yang Bekerja di Denpasar

\section{DAFTAR PUSTAKA}

Aamodt, M. G. (2010). Industrial/organizational psychology sixth edition. Belmont: Wadsworth.

BPS (Badan Pusat Statistik). (2014, December 17). Sosial Kependudukan. Diunduh dari bps.go.id: https://www.bps.go.id/linkTabelStatis/view/id/985 5 Agustus 2016.

BPS (Badan Pusat Statistik). (2016, April 4). Sosial Kependudukan. Diunduh dari bps.go.id: https://www.bps.go.id/linkTabelStatis/view/id/1907 5 Agustus 2016.

Creswell, J. W. (1998). Qualitative inquiry and research design. California: Sage Publication.

Dariyo, A. (2003). Psikologi perkembangan dewasa muda. Jakarta: PT.Gramedia Widiasarana Indonesia.

Ditindb. (2015). Warisan budaya tak benda. Kebudayaan. Kebudayaan Kemdikbud. Diunduh dari 
http://kebudayaan.kemdikbud.go.id/ditwdb/2015/12/17/son gket-sambas/ 9 Juli 2016.

Garber, P. R. (2004). Giving and receiving performance feedback. Amherst: HRD Press, Inc.

Gir/JPNN. (2016, March 21). Kisah gadis Sasak tak bisa menikah sebelum mahir menenun. Retrieved June 28, 2016, from JPNN. com Jaringan Berita Terluas di Indonesia: http://www.jpnn.com/read/2016/03/21/364756/Kisah-

Gadis-Sasak-Tak-Bisa-Menikah-Sebelum-Mahir-Menenun/page3

Faraby, M. E. (2014). Etos kerja pedagang etnis Madura di Pusat Grosir Surabaya ditinjau dari etika bisnis Islam. JESTT, 1(3), 178-189.

Hasbullah. (2011). Budaya kerja kaum perempuan Melayu: Studi terhadap perempuan pengrajin songket di Bukit Batu Kabupaten Bengkalis. Ejournal-UIN, 14(1), 14-30.

Herdiansyah, H. (2015). Metodologi penelitian kualitatif untuk ilmu Psikologi. Jakarta: Salemba Humanika.

Heslin, J. M. (2007). Sosiologi dengan pendekatan membumi. Jakarta: Erlangga.

Husni, I. (2014). Hubungan etos kerja dan kinerja guru di SMK Negeri 1 Lubuk Sikaping. Jurnal Administrasi pendidikan, 2(1), 341-831.

Irwin, D. M., \& Bushnell, M. M. (1980). Observational strategies for child study. United State of America: Library of Congress Cataloging in Publication Data.

Ismainar, H. (2015). Manajemen unit kerja. Yogyakarta: Deepublish.

Ivancevich, J. M., Konopaske, R., \& Matteson, M. T. (2007). Perilaku dan manajemen organisasi edisi ketujuh jilid 1 (terjemahan). Jakarta: Penerbit Erlangga.

Jaccard, J., \& Jacoby, J. (2010). Theory construction and modelbuilding skills. New York: The Guilford Press.

Kurniawan, B., \& Mariana, D. (2012). Persembahan perempuan untuk desa sebuah pendahuluan. Yogyakarta: IRE Yogyakarta.

Moleong, L. J. (2014). Metodologi penelitian kualitatif. Bandung: PT Remaja Rosdakarya.

Muhaimin, M. Y. (2013). Pengaruh etos kerja terhadap kinerja guru di Madrasah Ibtidaiyah Darul Huda Ngaglik Sleman Yogyakarta. (Skripsi tidak dipublikasikan). Fakultas Ilmu Tarbiyah dan Keguruan Universitas Islam Negeri Sunan Kalijaga, Yogyakarta.

Papalia, D. E., Olds, S. W., \& Feldman, R. D. (2009). Human development edisi 10. Jakarta: Salemba Humanika.

Pella, D. A., \& Inayati, A. (2011). Talent management mengembangkan SDM untuk mencapai pertumbuhan dan kinerja Prima. Jakarta: PT. Gramedia Pusaka Utama.

Probowati, Anna. (2012). Membangun sikap dan etos kerja. Jurnal Pengajar Jurusan Manajemen STIE Rajawali Purwerejo, Volume 1, 256-285.

Rasyidi, M. (2008). Studi nilai budaya pada lembaga adat suku Sasak sebagai kekuatan dalam membangun nilai luhur budaya bangsa. Jurnal Pertanian Universitas Mataram, 18(1-3), 7080.

Rosilawati, A. (2014). Perempuan dan pendidikan: Refleksi atas pendidikan berspektif gender. Jurnal Fakultas Tarbiyah dan Ilmu Keguruan Institut Agama Islam Negeri Pontianak,
156-122.

Retrieved

by

https://www.google.co.id/search?q=Perempuan +dan+ pendidikan\%3A+Refleksi+atas+pendidikan+berspektif+ge nder\&oq=Peremp

uan+dan+pendidikan\%3A+Refleksi+atas+pendidikan+bers pektif+gender\&aqs=chrome..69i57.415j0j4\&sourceid=chro me\&ie $=$ UTF- 8 .

Rostanti, Q. (2012, Juli 06). Memahami Lombok lewat perempuan Suku Sasak Terakhir. Leisure Republika. Diunduh dari http://www.republika.co.id/berita/senggang

/film/12/07/06/m6ox3h-memahami-lombok-lewatperempuan-sasak-terakhir 23 Desember 2015.

Rosyidi, A. (2012). Makna simbolis ornamen dan warna kain sesek desa Kambang Kerang kecamatan Aikmel Lombok Timur Nusa Tenggara Barat. (Skripsi tidak dipublikasikan). Universitas Negeri Yogyakarta, Yogyakarta.

Sinamo, J. (2011). 8 etos kerja profesional. Jakarta: Institt Darma Medika.

Smith, J. L. (2009, December). Interbusiness Issues. Peoriamagazine.com. Diunduh dari http://www.peoriamagazines.com/ibi/2009/dec/12-reasonsemployees-leave-organizations 9 Juli 2016.

Stewart, C. J., \& Cash, Jr., W. B. (2008). Interviewing principles and practices. New York: Mc Graw Hill.

Strauss, A., \& Corbin, J. (2013). Dasar-dasar penelitian kualitatif. Yogyakarta: Pustaka Pelajar.

Sudarsana, I. W. (2015, Maret 14). Gadis Sasak pantang menikah sebelum pandai menenun. Balitribune. Diunduh dari http://balitribune.co.id/2015/03/gadis-sasak-pantangmenikah-sebelum-pandai-menenun/ 9 Desember 2015.

Sugiyono. (2014). Metode penelitian pendidikan: Pendekatan kualitatif, kualitatif, R\&D. Bandung: Alfabeta.

Suryaningsih. (2013). Peluang kerja dan migrasi tenaga kerja wanita Indonesia. Jurnal FISIP Umrah, 2(2), 201-212.

Taylor, S. E., Peplau, L. A., \& Sears, D. O. (2009). Psikologi sosial edisi kedua belas. Jakarta: Kencana Predana Media Group.

Yusuf, A. M. (2014). Metode penelitian: Kualitatif, kuantitatif dan penelitian gabungan edisi pertama. Jakarta : Prenadamedia Group.

Yusuf, S. (2011). Dari titik nok: 5 strategi ampuh menjadi pengusahan sukses. Jakarta: Visimedia.

Yvonne, S., Krasono, O. M., \& Suprajitno, S. (2014). Etos kerja pegawai etnis Tionghoa di lima perusahaan keuangan Kota Surabaya. Student Journal Program Studi Sastra Tionghoa, Fakultas Sastra, Universitas Kristen Petra, 1(2), 33-41.

Waluya, B. (2007). Sosiologi: Menyelami fenomena sosial di masyarakat. Bandung: PT Grafindo Media Pratama. 